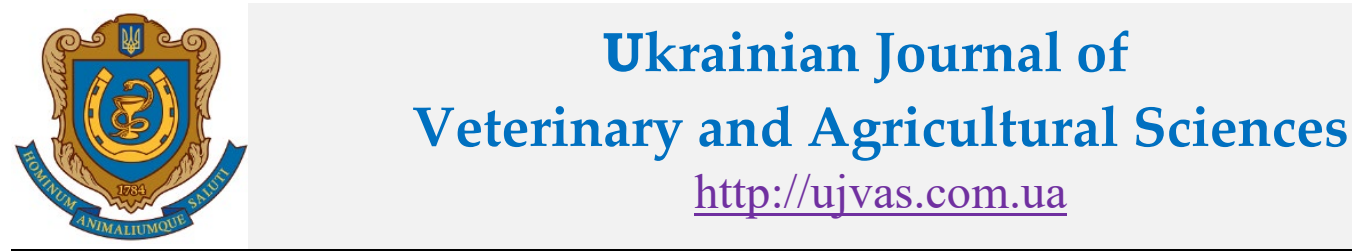

Stepan Gzhytskyi National University of Veterinary Medicine and Biotechnologies Lviv

original article $\mid$ UDC 636.2.015:636.082 $\mid$ doi: 10.32718/ujvas3-3.01

Volume 3

Number 3

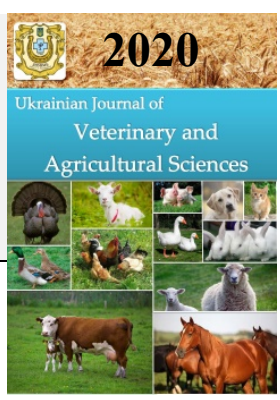

\title{
Energy evaluation of cows using genetic markers
}

\author{
N. Yu. Gubarenko \\ Dnipro State Agrarian and Economic University, S. Efremov Str., 25, Dnipro, 49600, Ukraine
}

\begin{tabular}{l} 
Article info \\
Received 30.06.2020 \\
Received in revised form \\
27.07 .2020 \\
Accepted 28.07.2020 \\
\hline Correspondence author \\
Natalia Gubarenko \\
Tel.: +38-067-564-16-57 \\
E-mail: gubarenkonata@i.ua \\
\hline
\end{tabular}

2020 Gubarenko N. This is an openaccess article distributed under the terms of the Creative Commons Attribution License, which permits unrestricted use, distribution, and reproduction in any medium, provided the original author and source are credited.

\section{(cc) $\mathrm{BY}$}

Contents

1. Introduction

2. Materials and methods ........

3 . Results and discussion .......

4. Conclusions ............... 7

References ....................

\begin{abstract}
The aim of the study was to research the polymorphism of allelic variants of somatotropin GH genes and pituitaryspecific transcription factor PIT-1 and its influence on bioenergetic parameters of high-yielding of Holstein breed cows in intensive milk production technology (cold method of growing heifers, early insemination of heifers. high daily operating loads on the body, etc.). Genotypes of cows were determined by PCR. Blood DNA was examined in a genetic laboratory. Isolation of genomic DNA was performed using resin "Chelex-100". The reaction was performed in an amplifier "Tertsyk". For the energy assessment of first-born cows used indicators of net maintenance energy (MJ per day), net milk energy (MJ per day), total net energy consumption (MJ per day), the value of the energy index (the share of energy released from milk, \%), productivity index (kilogram of $4 \%$ milk per $1 \mathrm{MJ}$ ), net energy consumption per $1 \mathrm{MJ}$ of milk (MJ), energy released with milk per $1 \mathrm{~kg}$ of metabolic mass (MJ). The best energy parameters in cows by GH gene - LL genotype, by pituitary-specific transcription factor PIT-1 - AB genotype, and among paired genotypes - LL/AB and LL/BB. In these animals, bioenergetic indicators for the first and second periods of lactation were higher than their peers of LV, BB and LV/BB genotypes by $2.0-15.2 \%$, with a reliable result for most traits. In particular, during the first lactation period, the advantage of cows of the LL/AB genotype over the LV/BB genotype in terms of bioenergetic indicators was 3.9-15.2 \%, significantly less than in the second lactation period in the range of $1.8-7.4 \%$. In the genome of pituitary-specific transcription factor PIT1 , better bioenergetic parameters were found in cows of genotype $\mathrm{AB}$ than in cows of genotype $\mathrm{BB}$. The difference in bioenergetic parameters is explained by the higher lactotropic function of the $\mathrm{L}$ and $\mathrm{A}$ alleles, and is the result of a greater complementary effect on the functioning of the alleles of the associated genes in the complex genotype. This was confirmed by the analysis of variance of one-factor complexes, which revealed a stronger influence of genotypes on bioenergetic parameters during the first period of lactation than the second. However, the strength of the influence of the paired genotype on the GH and PIT-1 genes was always high regardless of the lactation period and ranged from 8.9 to $20.9 \%(\mathrm{P}<0.01-0.001)$. In the future, it is of interest to study the formation of the exterior and constitution of cows of different genetic influences under the influence of polymorphisms in the GH and PIT-1 genes.
\end{abstract}

Key words: Polymorphism in GH and PIT-1 genes, pure support energy, pure milk energy, energy and productivity index.

Citation:

Gubarenko, N. Yu. (2020). Energy evaluation of cows using genetic markers. Ukrainian Journal of Veterinary and Agricultural Sciences, 3(3), 3-7.

\section{Introduction}

For the development of dairy farming requires new methods for assessing the biological characteristics of the animal body in terms of intensive technology of milk production at high operating loads on the body (VanRaden \& Sullivan, 2010; Mylostyvyi et al., 2019; Trakovická et al., 2019). One such method is the assessment of energy metabolism in dairy cows, in particular the determination of energy expenditure for live weight maintenance and milk synthesis (Petrenko et al., 2005). Some scientists have established the influence of the type of constitution on the energy performance of cows (Chernenko, 2012; Chernenko \& Chernenko, 2018) and ecogenesis (Denysyuk, 2009). Studies of the influence of the genotype of cows on the genes of somatotropin $\mathrm{GH}$ and pituitary-specific transcription factor PIT-1 have not been conducted before, which determines the relevance and scientific novelty of this problem.

\section{Materials and methods}

The research was conducted at PJSC "Agro-Soyuz" of Dnipropetrovsk region. The sample included one-year-old Holstein cows. The source material was DNA samples isolated from the blood of experimental animals. The PCR method was used to determine the polymorphism of marker genes (Burkat et al., 2009). The research was conducted under the guidance of specialists from the Laboratory of Genetic Control of the Institute of Pig Breeding and Agroindustrial Production of NAASU, Poltava. The method was used to conduct energy assessment of first-born cows (Petrenko et al., 2005). Biometric processing of the material was performed using MS Excel 2010. 


\section{Results and discussion}

\section{Results}

While analyzing the collected scientific data (Table 1), it can be noted that according to the results of energy evaluation of Holstein cows of different genotypes by the GH gene for the first lactation, animals of the LL genotype were the best. Compared to their peers of the LV genotype, they had per day higher indicators of net support energy spent on live weight maintenance and net milk energy spent on milk production, respectively by $1.9 \mathrm{MJ}(3.8 \%)$ at $\mathrm{P}<0.01$ and $7.5 \mathrm{MJ}(9.1 \%)$ for $\mathrm{P}<0.001$; higher total net energy consumption by $9.6 \mathrm{MJ}(7.2 \%)$ for $\mathrm{P}<0.001$. In these animals, the energy and productivity indices were higher by $1.3 \%(\mathrm{P}<0.01)$ and $0.01 \mathrm{~kg} / \mathrm{MJ}(\mathrm{P}<0.01)$, respectively. They had a lower net energy consumption per $1 \mathrm{MJ}$ of milk by $0.03 \mathrm{MJ}(1.8 \%)$ at $\mathrm{P}<0.01$ and they released slightly more energy with milk per $1 \mathrm{~kg}$ of metabolic mass by $0.03 \mathrm{MJ}(5.1 \%)$ at $\mathrm{P}<0.001$.

Table 1

Energy evaluation of Holstein cows of different genotypes by gene GH, $\bar{X} \pm S_{\bar{X}}$

\begin{tabular}{|c|c|c|c|c|}
\hline \multirow{3}{*}{ Feature } & \multicolumn{4}{|c|}{ Genotype of cows by growth hormone gene GH } \\
\hline & $\operatorname{LL}(\mathrm{n}=148)$ & $\mathrm{LV}(\mathrm{n}=20)$ & $\operatorname{LL}(\mathrm{n}=102)$ & $\mathrm{LV}(\mathrm{n}=13)$ \\
\hline & \multicolumn{2}{|c|}{ I lactation } & \multicolumn{2}{|c|}{ II lactation } \\
\hline Net support energy, MJ per day & $52.3 \pm 0.31 * *$ & $50.4 \pm 0.69$ & $53.1 \pm 0.31$ & $52.1 \pm 0.87$ \\
\hline Pure energy of milk, MJ per day & $89.6 \pm 0.81 * * *$ & $82.1 \pm 1.64$ & $112.6 \pm 1.15^{* *}$ & $102.8 \pm 2.71$ \\
\hline Total net energy consumption, MJ per day & $142.1 \pm 1.08 * * *$ & $132.5 \pm 2.22$ & $165.7 \pm 1.41 * *$ & $155.1 \pm 3.42$ \\
\hline $\begin{array}{l}\text { Energy index (share of energy released } \\
\text { with milk), } \%\end{array}$ & $63.2 \pm 0.14^{* *}$ & $61.9 \pm 0.31$ & $67.9 \pm 0.15^{* * *}$ & $66.3 \pm 0.41$ \\
\hline $\begin{array}{l}\text { Productive index, } \mathrm{kg} \mathrm{MCJ}(4 \%) \text { of milk } \\
\text { per } 1 \mathrm{MJ}\end{array}$ & $0.21 \pm 0.005^{* *}$ & $0.20 \pm 0.001$ & $0.22 \pm 0.001 * * *$ & $0.22 \pm 0.002$ \\
\hline $\begin{array}{l}\text { Net energy consumption per } 1 \mathrm{MJ} \text { of milk, } \\
\text { MJ }\end{array}$ & $1.59 \pm 0.003 * *$ & $1.62 \pm 0.008$ & $1.47 \pm 0.003 * * *$ & $1.51 \pm 0.009$ \\
\hline $\begin{array}{l}\text { Energy with milk per } 1 \mathrm{~kg} \text { of metabolic } \\
\text { mass, } \mathrm{MJ} \text { is allocated }\end{array}$ & $0.68 \pm 0.004 * * *$ & $0.65 \pm 0.007$ & $0.85 \pm 0.006^{* * *}$ & $0.79 \pm 0.014$ \\
\hline
\end{tabular}

Note: ${ }^{*}-\mathrm{P}<0,05 ; * *-\mathrm{P}<0.01 * * *-\mathrm{P}<0.001$ comparing with the genotype LV

The results of the energy evaluation of Holstein cows of different genotypes by the GH gene for the second lactation (see Table 1) show that animals of the LL genotype have a slightly higher indicator of net maintenance energy per live weight of $1.0 \mathrm{MJ}$ per day $(1.8 \%)$ and net energy for production milk at $9.8 \mathrm{MJ}$ per day $(9.5 \%)$ for $\mathrm{P}<0.01$; higher total net energy consumption by $10.6 \mathrm{MJ}(6.8 \%)$ at $\mathrm{P}<0.01$.

Furthermore, these animals had higher values of energy and productivity indices by $1.6 \%(\mathrm{P}<0.001)$ and
$0.01 \mathrm{~kg} / \mathrm{MJ}(\mathrm{P}<0.001)$, respectively, but lower net energy consumption per $1 \mathrm{MJ}$ of milk by $0.03 \mathrm{MJ}(2.3 \%)$ at $\mathrm{P}>0.999$ and more released energy with milk per $1 \mathrm{~kg}$ of metabolic mass at $0.06 \mathrm{MJ}(7.4 \%)$ at $\mathrm{P}<0.001$.

Having conducted an energy evaluation of Holstein cows of different genotypes by the PIT-1 gene during the first lactation, it was found that animals of both genotypes did not have significant differences in terms of net maintenance energy spent on live weight maintenance (Table 2).

Table 2

Energy evaluation of Holstein cows of different genotypes by gene PIT-1, $\bar{X} \pm S_{\bar{X}}$

\begin{tabular}{|c|c|c|c|c|}
\hline \multirow{3}{*}{ Feature } & \multicolumn{4}{|c|}{ Genotype of cows by growth hormone gene PIT-1 } \\
\hline & $\mathrm{AB}(\mathrm{n}=53)$ & $\mathrm{BB}(\mathrm{n}=113)$ & $\mathrm{AB}(\mathrm{n}=37)$ & $\mathrm{BB}(\mathrm{n}=78)$ \\
\hline & \multicolumn{2}{|c|}{ I Lactation } & \multicolumn{2}{|c|}{ II Lactation } \\
\hline Net support energy, MJ per day & $52.2 \pm 0.45$ & $52.1 \pm 0.35$ & $53.1 \pm 0.51$ & $52.9 \pm 0.36$ \\
\hline Pure energy of milk, MJ per day & $92.7 \pm 1.19 * * *$ & $87.1 \pm 0.93$ & $115.4 \pm 1.68 * *$ & $109.7 \pm 1.34$ \\
\hline Total net energy consumption, MJ per day & $144.9 \pm 1.57 * *$ & $139.1 \pm 1.25$ & $168.4 \pm 2.11 *$ & $162.6 \pm 1.64$ \\
\hline $\begin{array}{l}\text { Energy index (share of energy released with } \\
\text { milk), \% }\end{array}$ & $63.9 \pm 0.19 * * *$ & $62.4 \pm 0.14$ & $68.5 \pm 0.19 * * *$ & $67.4 \pm 0.17$ \\
\hline Productive index, $\mathrm{kg} \mathrm{MCJ}(4 \%)$ of milk per $1 \mathrm{MJ}$ & $0.21 \pm 0.002 *$ & $0.20 \pm 0.001$ & $0.22 \pm 0.001 * * *$ & $0.21 \pm 0.001$ \\
\hline Net energy consumption per $1 \mathrm{MJ}$ of milk, MJ & $1.57 \pm 0.005 * * *$ & $1.61 \pm 0.004$ & $1.46 \pm 0.004 * * *$ & $1.49 \pm 0.003$ \\
\hline $\begin{array}{l}\text { Energy with milk per } 1 \mathrm{~kg} \text { of metabolic mass, MJ } \\
\text { is allocated }\end{array}$ & $0.71 \pm 0.006^{* * *}$ & $0.67 \pm 0.003$ & $0.87 \pm 0.008 * * *$ & $0.83 \pm 0.007$ \\
\hline
\end{tabular}

However, in one year old cows of the AB genotype, the net energy consumption of milk was higher by $5.6 \mathrm{MJ}$ $(6.4 \%)$ at $\mathrm{P}<0.001$ and the total net energy consumption by $5.8 \mathrm{MJ}(4.1 \%)$ at $\mathrm{P}<0.01$; energy and productivity indices, respectively, by $1.5 \%$ for $\mathrm{P}<0.001$ and $0.01 \mathrm{~kg} / \mathrm{MJ}$ for $\mathrm{P}<0.05$, but lower net energy consumption per $1 \mathrm{MJ}$ of milk by $0.04 \mathrm{MJ}(2.7 \%)$ for $\mathrm{P}<0.001$. They released more energy with milk per $1 \mathrm{~kg}$ of metabolic mass at $0.04 \mathrm{MJ}$ $(6.5 \%)$ at $\mathrm{P}<0.001$.

Animals of different genotypes in the PIT-1 gene during the second lactation did not differ much in terms of net maintenance energy spent on live weight maintenance. 
However, one year old cows of genotype $\mathrm{AB}$ compared to peers of genotype BB had higher costs for pure energy of milk by $5.7 \mathrm{MJ}(5.2 \%)$ at $\mathrm{P}<0.01$ and total net energy consumption by $5.8 \mathrm{MJ}$ per day $(3.5 \%)$ at $\mathrm{P}<0.05$; energy and productivity indices, respectively, by $1.1 \%$ for $\mathrm{P}<0.001$ and $0.01 \mathrm{~kg} / \mathrm{MJ}(6 \%)$ for $\mathrm{P}<0.001$. In this group of animals, the net energy expenditure per $1 \mathrm{MJ}$ of milk was lower by $0.04 \mathrm{MJ}(2.7 \%)$ at $\mathrm{P}>0.999$ and they released more energy with milk per $1 \mathrm{~kg}$ of metabolic mass by 0.04 $\mathrm{MJ}(5.1 \%)$ at $\mathrm{P}<0.001$.

Having conducted an energy assessment of Holstein cows of complex genotypes during the first lactation, it was found that the best traits are characterized by individuals of the LL/AB genotype, which compared to the LV/BB genotype had a higher net maintenance energy of $2.2 \mathrm{MJ}$ per day $(3.9 \%)$ at $\mathrm{P}<0.05$ and net milk energy by $12.3 \mathrm{MJ}(15.2 \%)$ at $\mathrm{P}<0.001$; higher total net energy consumption by 14.2 MJ per day $(10.9 \%)$ at $\mathrm{P}<0.001$; higher energy and productivity indices, respectively, by $2.4 \%$ for $\mathrm{P}<0.001$ and $0.01 \mathrm{~kg} / \mathrm{MJ}(3.9 \%)$ for $\mathrm{P}<0.001$. These animals have a lower net energy expenditure per $1 \mathrm{MJ}$ of milk by $0.06 \mathrm{MJ}$ $(3.7 \%)$ at $\mathrm{P}<0.001$ and more emit energy with milk per $1 \mathrm{~kg}$ of metabolic mass by $0.07 \mathrm{MJ}(10.9 \%)$ at $\mathrm{P}<0.001$ (Table 3).

\section{Table 3}

Energy characteristics of Holstein cows of complex genotypes during the first lactation, $\bar{X} \pm S_{\bar{x}}$

\begin{tabular}{lrrr}
\hline \multicolumn{1}{c}{ Feature } & \multicolumn{3}{c}{ Cows Genotype } \\
\cline { 2 - 5 } & $\begin{array}{c}\text { LL/AB, } \\
\mathrm{n}=49\end{array}$ & $\begin{array}{c}\text { LL/BB, } \\
\mathrm{n}=95\end{array}$ & $\begin{array}{c}\mathrm{LV} / \mathrm{BB}, \\
\mathrm{n}=17\end{array}$ \\
\hline Net support energy, MJ per day & $52.2 \pm 0.49^{*}$ & $52.3 \pm 0.36^{*}$ & $50.2 \pm 0.76$ \\
Pure energy of milk, MJ per day & $92.7 \pm 1.29 * * *$ & $88.1 \pm 1.03 * * *$ & $80.5 \pm 1.59$ \\
Total net energy consumption, MJ per day & $144.9 \pm 1.71^{* * *}$ & $140.4 \pm 1,35^{* * *}$ & $130.7 \pm 2.27$ \\
Energy index (share of energy released with milk), \% & $63.9 \pm 0.22^{* * *}$ & $62.7 \pm 0.16^{* * *}$ & $61.6 \pm 0.26$ \\
Productive index, kg MCJ (4 \%) of milk per 1 MJ & $0.21 \pm 0.001^{* * *}$ & $0.22 \pm 0.002^{* * *}$ & $0.19 \pm 0.001$ \\
Net energy consumption per 1 MJ of milk, MJ & $1.56 \pm 0.005^{* * *}$ & $1.61 \pm 0.004 * * *$ & $1.63 \pm 0.006$ \\
Energy with milk per 1 kg of metabolic mass, MJ is allocated & $0.71 \pm 0.006^{* * *}$ & $0.71 \pm 0.006^{* * *}$ & $0.64 \pm 0.007$ \\
\hline
\end{tabular}

One year old cows of the LL/BB genotype took an intermediate position in all bioenergetic traits, but when compared with peers of the LV/BB genotype, there is a significant and probable difference in favor of individuals in this group.

In Holstein cows of complex genotypes during the second lactation, significant differences in net maintenance energy spent on live weight maintenance were not found. However, peers of the LL/AB genotype compared to their peers of the LV/BB genotype showed higher milk energy expenditures by $14.6 \mathrm{MJ}$ per day $(14.5 \%)$ at $\mathrm{P}<0.001$; higher total net energy consumption by $15.8 \mathrm{MJ}$ per day $(10.4 \%)$ at $\mathrm{P}<0.001$; higher energy and productivity indices, respectively, by $2.5 \%$ for $\mathrm{P}<0.001$ and $0.02 \mathrm{~kg} / \mathrm{MJ}$ $(7.1 \%)$ for $\mathrm{P}<0.001$. Animals in this group have lower net energy expenditure per $1 \mathrm{MJ}$ of milk by $0.05 \mathrm{MJ}(3.6 \%)$ $\mathrm{P}<0.001$ and more emit energy with milk per $1 \mathrm{~kg}$ of metabolic mass by $0.09 \mathrm{MJ}(11.9 \%$ ) at $\mathrm{P}<0.001$ (Table 4).

\section{Table 4}

Energy characteristics of Holstein cows of complex genotypes during the second lactation, $\bar{X} \pm S_{\bar{x}}$

\begin{tabular}{lccc}
\hline \multirow{2}{*}{ Feature } & \multicolumn{3}{c}{ Cows genotype } \\
\cline { 2 - 4 } & $\mathrm{LL} / \mathrm{AB}, \mathrm{n}=34$ & $\mathrm{LL} / \mathrm{BB}, \mathrm{n}=66$ & $\mathrm{LV} / \mathrm{BB}, \mathrm{n}=11$ \\
\hline Net support energy, MJ per day & $52.9 \pm 0.55$ & $53.1 \pm 0.39$ & $51.7 \pm 0.99$ \\
Pure energy of milk, MJ per day & $115.5 \pm 1.82^{* * *}$ & $111.3 \pm 1.45^{* *}$ & $100.9 \pm 2.81$ \\
Total net energy consumption, MJ per day & $168.4 \pm 2.31^{* * *}$ & $164.4 \pm 1.78^{* *}$ & $152.6 \pm 3.59$ \\
Energy index (share of energy released with milk), \% & $68.5 \pm 0.21^{* * *}$ & $67.6 \pm 0.18^{* *}$ & $66.1 \pm 0.43$ \\
Productive index, kg MCJ (4 \%) of milk per 1 MJ & $0.23 \pm 0.001^{* * *}$ & $0.22 \pm 0.002^{* *}$ & $0.21 \pm 0.002$ \\
Net energy consumption per 1 MJ of milk, MJ & $1.46 \pm 0.004^{* * *}$ & $1.48 \pm 0.004^{* *}$ & $1.51 \pm 0.011$ \\
Energy with milk per 1 kg of metabolic mass, MJ is & $0.87 \pm 0.008^{* * *}$ & $0.84 \pm 0.007^{* * *}$ & $0.78 \pm 0.015$ \\
allocated & & & \\
\hline
\end{tabular}

In its turn, the animals of the LL/BB genotype were slightly inferior to the peers of the LL/AB genotype in terms of the value of the studied traits, but in comparison with the animals of the LV/BB genotype a significant difference in net milk energy was found by $10.4 \mathrm{MJ}$ per day $(10.3 \%)$ at $\mathrm{P}<0.01$, total net energy consumption by $11.8 \mathrm{MJ}$ per day $(7.7 \%)$ at $\mathrm{P}<0.01$; the energy and productivity indices were higher, respectively, by $1.5 \%$ at $\mathrm{P}<0.01$ and $0.01 \mathrm{~kg} / \mathrm{MJ}$ $(4.7 \%)$ at $\mathrm{P}<0.01$. The cows of this group had slightly lower net energy consumption per $1 \mathrm{MJ}$ of milk by $0.03 \mathrm{MJ}$ $(2.2 \%)$ at $\mathrm{P}<0.01$ and more energy was released from milk per $1 \mathrm{~kg}$ of metabolic mass by $0.06 \mathrm{MJ}(7.2 \%)$ at $\mathrm{P}<0.001$.
The share of genotype influence on bioenergetic parameters of cows during the first lactation is presented in table. 5 .

Thus, the share of the genotype of the GH growth hormone genotype on net support energy was in the range of $8.0 \%$ at $\mathrm{P}<0.01$, on pure milk energy $7.8 \%$ at $\mathrm{P}<0.01$, total net energy expenditure $5.5 \%$ at $\mathrm{P}<0.05$, energy and productivity indices, respectively 18.4 and $18.3 \%$ for $\mathrm{P}<0.001$, for net energy consumption per $1 \mathrm{MJ}$ of milk $17.8 \%$ for $\mathrm{P}<0.001$, for energy released with milk per $1 \mathrm{~kg}$ of metabolic mass $19.3 \%$ for $\mathrm{P}<0.001$. 


\section{Table 5}

The share of genotype influence on bioenergetic parameters of cows during the first lactation, $\eta_{x}^{2}, \%$

\begin{tabular}{lccc}
\hline \multicolumn{1}{c}{ Feature } & \multicolumn{2}{c}{ Genotype } \\
\cline { 2 - 4 } & $\mathrm{GH}$ & $\mathrm{PIT}-1$ & $\mathrm{GH} / \mathrm{PIT}-1$ \\
\hline Pure support energy & $8.0^{* *}$ & $6.9^{* *}$ & $11.9^{* * *}$ \\
Pure energy of milk & $7.8^{* *}$ & $7.1^{* * *}$ & $12.2^{* * *}$ \\
Total net energy consumption & $5.5^{*}$ & $4.2^{* *}$ & $9.4^{* * *}$ \\
Energy index (share of energy released with milk), $\%$ & $18.4^{* * *}$ & $18.5^{* * *}$ & $20.4^{* * *}$ \\
Productive index, kg MCJ (4 \%) of milk per 1 MJ & $18.3^{* * *}$ & $18.2^{* * *}$ & $20.5^{* * *}$ \\
Net energy consumption per 1 MJ of milk & $17.8^{* * *}$ & $17.9^{* * *}$ & $20.1^{* * *}$ \\
Energy with milk per 1 kg of metabolic mass is released & $19.3^{* * *}$ & $19.1^{* * *}$ & $20.8^{* * *}$ \\
\hline
\end{tabular}
Note: *-P<0.05;**-P<0.01;***-P<0.001

The share of the influence of the genotype by the RIT-1 gene on net energy of support was $6.9 \%$ for $\mathrm{P}<0.01$, on pure milk energy $7.1 \%$ for $\mathrm{P}<0.001$, total net energy consumption $4.2 \%$ for $\mathrm{P}<0.01$, energy and productivity indices, respectively 18.5 and $18.2 \%$ for $\mathrm{P}<0.001$, for net energy consumption per $1 \mathrm{MJ}$ of milk $17.9 \%$ for $\mathrm{P}<0.001$, for energy released with milk per $1 \mathrm{~kg}$ of metabolic mass $19.1 \%$ for $\mathrm{P}<0.001 .1$.

According to the complex genotype GH/PIT-1, the share of impact on net energy of support was in the range of $11.9 \%$ for $\mathrm{P}<0.001$, for pure energy of milk $12.2 \%$ for $\mathrm{P}<0.001$, total net energy consumption $9.4 \%$ for $\mathrm{P}<$ 0.001 , energy and productivity indices, respectively 20.4 and $20.5 \%$ for $\mathrm{P}<0.001$, for net energy consumption per 1
MJ of milk $20.1 \%$ for $\mathrm{P}<0.001$, for energy released with milk per $1 \mathrm{~kg}$ of metabolic mass $20.8 \%$ for $\mathrm{P}<0.001$.

The share of genotype influence on bioenergetic parameters of cows during the second lactation is presented in table 6 . Thus, the share of the influence of the genotype for the GH growth hormone gene on all indicators of energy evaluation of cows during the second lactation was slightly less than during the first lactation and was: net maintenance energy was $6.1 \%$ at $\mathrm{P}<0.01$; for net energy of milk $6.9 \%$ at $\mathrm{P}<0.01$; for total net energy consumption $5.6 \%$ at $\mathrm{P}<0.05$; on energy and productivity indices, respectively 10.1 and $10.0 \%$ for $\mathrm{P}<0.05$; for net energy consumption per $1 \mathrm{MJ}$ of milk $10.1 \%$ at $\mathrm{P}<0.001$; on the released energy with milk per $1 \mathrm{~kg}$ of metabolic mass $9.8 \%$ at $\mathrm{P}<0.001$.

Table 6

The share of genotype influence on bioenergetic parameters of cows during the second lactation, $\eta_{x}^{2}, \%$

\begin{tabular}{lccc}
\hline \multicolumn{1}{c}{ Feature } & \multicolumn{2}{c}{ Genotype } \\
\cline { 2 - 3 } & GH & PIT-1 & GH/PIT-1 \\
\hline Pure support energy & $6.1^{* *}$ & $4.9^{*}$ & $11.1^{* *}$ \\
Pure energy of milk & $6.9^{* *}$ & $5.2^{*}$ & $11.5^{* *}$ \\
Total net energy consumption & $5.6^{*}$ & $3.7^{*}$ & $8.9^{* *}$ \\
Energy index (share of energy released with milk), $\%$ & $10.1^{* * *}$ & $11.7^{* * *}$ & $20.7^{* * *}$ \\
Productive index, kg MCJ (4 \%) of milk per 1 MJ & $10.0^{* * *}$ & $11.3^{* * *}$ & $20.9^{* * *}$ \\
Net energy consumption per 1 MJ of milk & $10.1^{* * *}$ & $11.7^{* * *}$ & $20.7^{* * *}$ \\
Energy with milk per 1 kg of metabolic mass is released & $9.8^{* * *}$ & $11.6^{* * *}$ & $20.2^{* * *}$ \\
\hline
\end{tabular}

The share of the influence of the RIT-1 gene genotype on the studied parameters during the second lactation was also smaller than during the first lactation period and was: on the net support energy $4.9 \%$ at $\mathrm{P}<0.05$; for pure energy of milk $5.2 \%$ at $\mathrm{P}<0.05$; for total net energy consumption $3.7 \%$ at $\mathrm{P}<0.05$; on energy and productivity indices, respectively 11.7 and $11.3 \%$ for $\mathrm{P}<0.001$; for net energy consumption per $1 \mathrm{MJ}$ of milk $11.7 \%$ at $\mathrm{P}<0.001$; on the released energy with milk per $1 \mathrm{~kg}$ of metabolic mass $11.6 \%$ at $\mathrm{P}<0.001$.

According to the complex genotype GH/PIT-1 for the second lactation, the share of influence on the indicators of energy evaluation of cows remained almost unchanged and was: on net energy support $11.1 \%$ at $\mathrm{P}<0.01$; for net energy of milk $11.5 \%$ at $\mathrm{P}<0.01$; for total net energy consumption $8.9 \%$ at $\mathrm{P}<0.01$; on energy and productivity indices, respectively 20.7 and $20.9 \%$ for $\mathrm{P}<0.001$; for net energy consumption per $1 \mathrm{MJ}$ of milk $20.7 \%$ at $\mathrm{P}<0.001$; on the released energy with milk per $1 \mathrm{~kg}$ of metabolic mass of $20.2 \%$ at $\mathrm{P}<0.001$, which indicates a general positive energy balance in the body of these animals.

\section{Discussion}

The analysis of variance of one-factor complexes revealed the peculiarities of the influence of polymorphism in the GH and PIT-1 genes on the bioenergetic parameters of cows in the context of the first two lactations. In particular, during the first and second periods of lactation, each genotype of the GH and PIT-1 gene has a different effect on these traits - a stronger effect in the first lactation than in the second. Perhaps this is due to even more intensively growing first-born cows with their greater dependence on the function of the growth hormone $\mathrm{GH}$ gene and pituitaryspecific transcription factor PIT-1 (Zhao et al., 2004). However, the strength of the influence of the paired genotype on the gene GH and PIT-1 remains equally high regardless of the lactation period. This is the result of greater complementary functioning of associated genes and their alleles in the complex genotype (Shariflou et al., 2000; Akyuz et al., 2015). Our data coincide with the results of research by other scientists (Krupin \& Shakirov, 2019), who evaluated the energy performance of cows depending on the polymorphism in several genes, including the GH and PIT-1 genes. 


\section{Conclusions}

Bioenergetic parameters of highly productive cows with their intensive use depend on the polymorphism in the genes GH and PIT-1. In cows with LL genotype by GH gene and cows with $\mathrm{AB}$ genotype by pituitary-specific transcription factor PIT-1 gene, as well as by polymorphism in both genes, i.e. paired LL/AB and LL/BB genotypes, bioenergetic parameters for the first and second lactation periods were higher than their peers of LV, BB and LV/BB genotypes by $2.0-15.2 \%$ with a reliable result for most traits $(\mathrm{P}<0.01-$ 0.001 ). The effect of polymorphism in the GH and PIT-1 genes was stronger in the first period of lactation than in the second. However, polymorphism of the paired genotype for these genes has always had a more pronounced effect on the signs of energy evaluation of cows. The share of its influence, according to the results of analysis of variance, ranged from 8.9 to $20.9 \%(\mathrm{P}<0.01-0.001)$.

\section{References}

Akyuz, B., Agaoglu, O. K., Akcay, A., \& Agaoglu, A. R. (2015). Effects of DGAT1 and GH polymorphism on milk yield in Holstein cows reared in Turkey. Slovenian Veterinary Research, 52(4), 185-191. Available at: https://www.slovetres.si/index.php/SVR/article/view/147.

Burkat, V. P., Kopylov, K. V., \& Kopylova, K. V. (2009). DNKdiagnostyka vely koyi rogatoyi hudoby $\mathrm{v}$ systemi genomnoyi selekciyi [DNA diagnostics of cattle in the system of genomic selection] (metodychni rekomendaciyi). Kyyiv (in Ukrainian).

Chernenko, O. I. (2012). Produktyvnist ta rezultaty energetychnoyi ocinky koriv ukrayinskoyi chervonoyi molochnoyi porody zalezhno vid konstytucionalnyh osoblyvostej [Productivity and results of energy assessment of Ukrainian red dairy cows depending on constitutional features]. Naukovyj visnyk "Askaniya Nova". "PYEL", 5(2), 176-180 (in Ukrainian).
Chernenko, O. M., \& Chernenko, O. I. (2018). Economic trait of cows with different duration of prenatal growth period. Theoretical and Applied Veterinary Medicine, 6(3), 23-28. doi: 10.32819/2018.63005.

Denysyuk, O. V. (2009). Energetychna ocinka pervistok, otrymanyh vid batkiv riznogo ekogenezu [Energy assessment of firstborns received from parents of different ecogenesis]. Visnyk Instytutu tvarynnycztva centralnyh rajoniv UAAN, 6, 39-43 (in Ukrainian)

Krupin, E. O., \& Shakirov, Sh. K. (2019). Influence of CSN3, LGB, PRL, GH, TG5 genes alleles on dairy productivity and energy value of cow's milk. Carpathian Journal of food science and technology, 11(4), 104-115. doi: 10.34302/2019.11.4.9.

Mylostyvyi, R., Chernenko, O., \& Lisna, A. (2019). Prediction of comfort for dairy cows, depending on the state of the environment and the type of barn. Monograph: Development of Modern Science: The Experience of European Countries and Prospects for Ukraine. doi: 10.30525/978-9934-571-78-7 53.

Petrenko, V. I., Barabash, V. I., \& Docenko, L. V. (2005). Energetychna ocinka velykoyi rogatoyi hudoby [Energy assessment of cattle]. Rozvedennya i genetyka tvaryn, 39, 152-157 (in Ukrainian).

Shariflou, M. R., Moran, C., \& Nicholas, F. W. (2000). Association of the Leu127 variant of the bovine growth hormone (bGH) gene with increased yield of milk, fat, and protein in Australian Holstein-Friesians. Australian Journal of Agricultural Research, 51(4), 515-522. doi: 10.1071/ar99102.

Trakovická, A., Vavrišínová, K., Gábor, M., Miluchová, M., Kasarda, R., \& Moravčíková, N. (2019). The impact of diacylglycerol O-acyltransferase 1 gene polymorphism on carcass traits in cattle. Journal of Central European Agriculture, 20(1), 12-18. doi: 10.5513/jcea01/20.1.2411.

VanRaden, P. M., \& Sullivan, P. G. (2010). International genomic evaluation methods for dairy cattle. Genetics Selection Evolution, 42(1), 7. doi: 10.1186/1297-9686-42-7.

Zhao, Q., Davis, M. E., \& Hines, H. C. (2004). Associations of polymorphisms in the Pit-1 gene with growth and carcass traits in Angus beef cattle12. Journal of Animal Science, 82(8), 2229-2233. doi: 10.2527/2004.8282229x. 